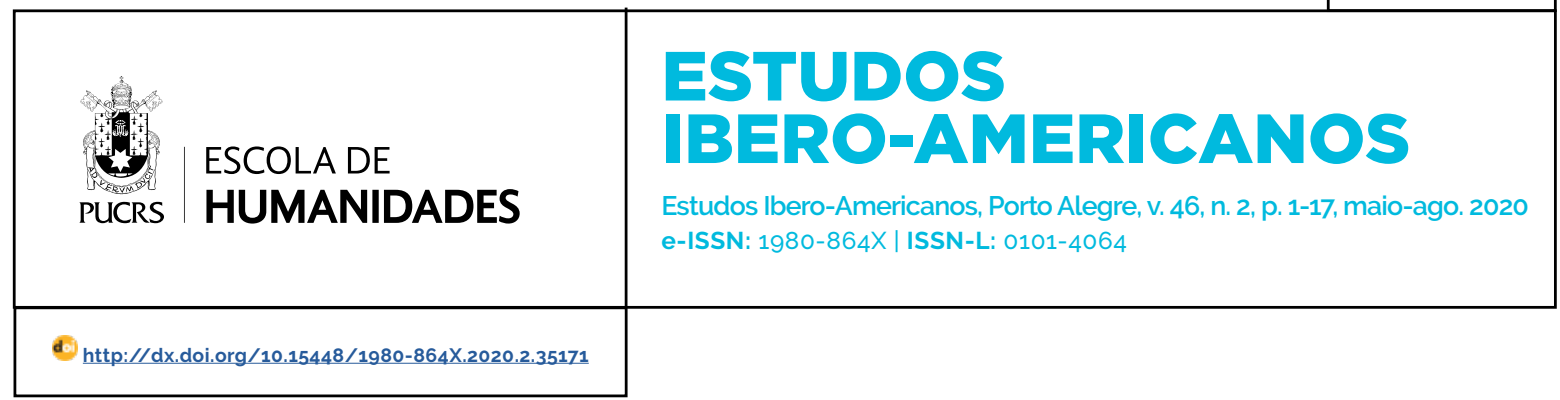

SEÇÃO: DOSSIÊ

\title{
O velho oeste transforma-se num celeiro agrícola: imprensa, colonização e historicidade entre refugiados da Segunda Guerra no Brasil (Guarapuava/PR) ${ }^{\mathbf{1}}$
}

\author{
The old west turns into an agricultural barn: press, colonization and historicity among \\ World War II refugees in Brazil (Guarapuava/PR) \\ El viejo oeste se convierte en un granero agricola: prensa, colonización y historicidad \\ entre refugiados de la Segunda Guerra Mundial en Brasil (Guarapuava/PR)
}

\section{Marcos Nestor Stein² \\ orcid.org/0000-0002-2623-0686 \\ mancha36@hotmail.com}

Beatriz Anselmo Olinto 3 orcid.org/0000-0002-6520-0711 biaolinto@hotmail.com

Recebido em: 27 ago. 2019. Aprovado em: 13 jul. 2020. Publicado em: 25 ago. 2020.

\section{(C) (i)}

Artigo está licenciado sob forma de uma licença Creative Commons Atribuição 4.0 Internacional.
Resumo: o artigo enfoca narrativas publicadas em 1991 e 1992 pelo Jornal de Entre Rios em comemoração aos 40 anos de fundação do distrito de mesmo nome no municipio de Guarapuava, região centro-sul do Paraná. A localidade de Entre Rios foi fundada entre março de 1951 e janeiro de 1952, com a fixação de cerca de 2.500 imigrantes refugiados da Segunda Guerra Mundial, oriundos de áreas da antiga lugoslávia, Hungria e Romênia, que se identificam coletivamente como suábios do Danúbio e estavam exilados desde 1944, na Áustria. O recorte proposto pelo presente artigo é analisar as formas como diferentes eventos são narrados pelo referido Jornal, articulando-os a diferentes temporalidades. Serão analisadas as discursividades que envolvem essas narrativas sobre o passado do grupo da Europa, sobre os primeiros anos no Brasil, o presente da comunidade e as suas expectativas de futuro, destacando-se as formas de ligação dessas temporalidades com noções de historicidade e de desenvolvimento agrícola.

Palavras-chave: História rural. Suábios do Danúbio. Identidade. Historicidade.

Abstract: the paper aims to analyze narratives published in 1991 and 1992 by the Journal of Entre Rios in commemoration of the 40th' birthday of the district founding, in Guarapuava, Paraná, Brazil. Entre Rios's district was founded between March 1951 and January 1952, with the settlement of 2,500 refugee immigrants of World War II coming from areas of the former Yugoslavia, Hungary and Romania, who collectively identify themselves as Danube Swabian and had been exiled since 1944 in Austria. The focus of this paper is to analyze how the events are narrated by the referred newspaper, articulating them to different temporalities. The narratives involved about: the past of the group of Europe, the early years in Brazil, the present of the community and their expectations of the future, relating ideas about time, history and agricultural development of Entre Rios.

Keywords: Rural History. Danube Swabians. Identity. Historicity.

Resumen: el artículo enfoca narrativas publicadas en 1991 y 1992 por el Jornal de Entre Rios en conmemoración a los 40 años de fundación del distrito de mismo nombre en el municipio de Guarapuava, región centro sur de Paraná. La localidad de Entre Rios fue fundada entre marzo de 1951 y enero de 1952, con la fijación de cerca de 2.500 inmigrantes refugiados de la Segunda Guerra Mundial, derivados de áreas de la antigua Yugoslavia, Hungria y Rumania, que se identifican colectivamente como suábios do Danúbio y estaban exilados desde 1944 en Austria. El recorte propuesto por el presente artículo es analizar las formas como diferentes eventos son narrados por el referido periódico, articulándolos a diferentes temporalidades. Serán analizadas las discursividades que involucran

O artigo é um dos resultados dos estágios de pós-doutorado sêniores desenvolvidos pelos autores na Universidade Federal Fluminense (UFF). As pesquisas desenvolvidas nos estágios são vinculadas ao INCT Proprietas: História Social da Propriedade e Direitos de Acesso, coordenado pela professora Márcia Maria Menendes Motta. O presente trabalho foi realizado com apoio da Coordenação de Aperfeiçoamento de Pessoal de Nivel Superior - Brasil (Capes) - Código de Financiamento 001.

2 Universidade Estadual do Oeste do Paraná (UNIOESTE), Marechal Cândido Rondon, PR, Brasil.

3 Universidade Estadual do Centro Oeste do Paraná (UNICENTRO), Guarapuava, PR, Brasil. 
esas narrativas sobre el pasado del grupo de Europa, sobre los primeros años en Brasil, el presente de la comunidad y sus expectativas de futuro, destacándose las formas de enlace de esas temporalidades con nociones de historicidad y de desarrollo agricola. Palabras clave: Historia rural. Suábios do Danúbio. Identidad. Historicidad.

\section{Introdução}

Em 6 de junho de 1951, no Porto de Santos, em São Paulo, desembarcaram 222 refugiados da Segunda Guerra Mundial que se autoidentificam como suábios do Danúbio (Donauschwaben). Tratava-se do primeiro grupo de um total de sete levas de migrantes que, até meados de 1952. formaram um contingente de cerca de 2.500 pessoas. De Santos, os grupos viajaram de trem até o município de Guarapuava, Paraná, onde fundaram a colônia Entre Rios (FRÖSCH, 1958; STEIN, 2011).

A designação "suábios do Danúbio" foi criada em 1922 pelos geógrafos Robert Sieger e Hermann Rüdiger para identificar os habitantes de áreas da antiga lugoslávia, Romênia e Hungria cujos antepassados migraram nos séculos XVIII e XIX de várias partes do Sacro Império Romano Germânico após a expulsão dos turcos otomanos da região (STEIN, 2011; SCHERER, 1964).

Durante a Segunda Guerra Mundial, a região foi ocupada pelo exército alemão. Muitos suábios fizeram parte, voluntariamente ou recrutados, das forças nazistas, inclusive com a criação da divisão de montanha da SS Príncipe Eugênio (SS-Division Prinz Eugen), ${ }^{4}$ cuja principal missão era combater a resistência partisan chefiada pelo marechal Tito. ${ }^{5}$ Com a vitória dos partisans e o avanço do exército soviético, milhares de suábios refugiaram-se na Áustria. Muitos dos que permaneceram foram mortos, presos ou enviados para campos de trabalho forçado na União Soviética. ${ }^{6}$

Em 1949, a organização humanitária denominada Ajuda Suiça para a Europa (Schweizer
Europahilfe) coordenou as ações de uma comissão enviada ao Brasil para examinar possiveis áreas para a fixação dos suábios que estavam na Áustria. Após negociações com os governos brasileiro e paranaense, decidiu-se desapropriar uma área de aproximadamente 22.000 hectares ocupados por fazendas de criação de gado no município de Guarapuava, centro-sul do Paraná, para o estabelecimento dos suábios do Danúbio (STEIN; OLINTO; FROTSCHER, 2017). A distribuição dos recém-chegados na área se deu sob a coordenação da Cooperativa Agrária, em cinco vilas: Vitória, que se tornou a sede de Entre Rios; Cachoeira; Socorro; Samambaia; e Jordãozinho.

O principal argumento do Governo paranaense para apoiar o projeto de criação da colônia era que a sua instalação iria resultar no aumento da produção de trigo. Entretanto, nos primeiros anos, essa expectativa não se concretizou, especialmente, em função de problemas ligados ao clima e ao solo. As péssimas colheitas e conflitos entre os colonos resultaram em um processo de êxodo, com a saida de mais da metade dos imigrantes. ${ }^{7}$ Esse movimento de saída começou a diminuir a partir da década de 1960, quando a Cooperativa Agrária, com financiamentos e subsídios do Governo brasileiro e o envio de recursos por parte da República Federal da Alemanha, iniciou um processo de aquisição de áreas de terras dos arredores da colônia e de municipios vizinhos, que foram distribuidas aos seus associados, constituindo propriedades com área mínima de 100 hectares $^{8}$ e dedicadas, principalmente, à produção de trigo, soja, centeio e cevada, por meio do uso de máquinas, adubos e agrotóxicos. Além disso, no início da década de 1980, em parceria com a Cia. Antártica Paulista, teve início a produção e industrialização de malte cervejeiro.

Esse processo envolvendo aquisição de terras,

4 O nome é alusivo ao principe Eugênio de Savoia (1663-1736), que comandou os exércitos austriacos nas vitórias contra os turcos otomanos no século XVII.

5 Sobre a Divisão de Montanha SS Príncipe Eugênio, ver: CASAGRANDE, 2001

6 É o caso de Katharina Hech. Em 1944, aos 17 anos de idade, ela foi aprisionada e enviada para campos de trabalhos forçados na Ucrânia. Para uma análise de suas narrativas orais, ver: Frotscher e Stein (2016, p. 175-202) e Frotscher, Stein e Olinto (2014).

Entre 1951 e 1971 deixaram a colônia 1.776 pessoas. Cerca de 90\% emigraram para a República Federal da Alemanha. Outros se fixaram em cidades como Curitiba e São Paulo (ELFES, 1971, p. 58-59).

8 A justificativa para o tamanho mínimo das propriedades baseava-se na viabilidade econômica para a aquisição de máquinas para a realização do trabalho agrícola (COOPERATIVA AGRÁRIA MISTA ENTRE RIOS LTDA., 1976). 
industrialização e aumento da produção agricola foi acompanhado, especialmente, em momentos comemorativos, pela produção e divulgação de discursos sobre os suábios e a colônia Entre Rios. Em 1971, em função dos 20 anos de Entre Rios, a cooperativa financiou a publicação do livro Suábios no Paraná e, em 1976, em função dos 25 anos, foi publicado o livro Entre Rios: documentário ilustrado da colonização suábia danubiana. ${ }^{9} \mathrm{Em}$ dezembro de 1986 foi publicada a edição teste do Jornal de Entre Rios, periódico em língua portuguesa e alemã que passaria a divulgar notícias sobre a colônia. Além disso, especialmente em ocasiões como os aniversários de fundação de Entre Rios, o jornal publicava narrativas sobre o passado dos suábios do Danúbio na Europa, sobre a fundação da colônia e seu desenvolvimento no passado, presente e futuro.

Diante disso, neste artigo a análise abordará as narrativas publicadas pelo Jornal de Entre Rios entre 1991 e 1992. Em nossa análise do periódico nos inspiramos nas reflexões de Tânia Regina de Luca. De acordo com ela, o estudo do conteúdo dos periódicos deve articular os objetivos, a estrutura, seus sentidos e "[...] é preciso atentar para os responsáveis e colaboradores mais assiduos pois, na maioria das vezes, revistas e jornais constituemse em projetos coletivos." (LUCA, 2008, p.118).

O recorte refere-se ao período no qual foram divulgadas notícias sobre as comemorações dos 40 anos da fundação de Entre Rios. A escolha do material se dá em função da relação estabelecida nos discursos do periódico entre comemorar o presente, narrar um passado e projetar um futuro para esse grupo.

\section{0 jornal: técnicas e narrativas a serviço da identidade}

O Jornal de Entre Rios teve seu primeiro número, chamado de "Edição-teste", publicado em dezembro de 1986. Em sua capa, o jornal se autodefiniu para seus leitores como um "[...] informativo, noticioso e analítico 'suábio-brasileiro', publicado em português e alemão."10 Nessa edição o caráter comemorativo do periódico foi estabelecido, pois que sua primeira reportagem de capa tratava de duas comemorações locais: o aniversário de Entre Rios - "Colonização completa 35 anos" - e, logo abaixo, com letras um pouco menores, o aniversário de Guarapuava - "Guarapuava comemorou os 167 anos". Dividiam tal capa, além dessas manchetes, dois boxes com os seguintes anúncios: "Plantação de soja em MT suplanta a do PR" e "Quase 2 mil votaram em Entre Rios." ${ }^{11}$

Em seu primeiro número podem ser traçadas três linhas editoriais que perpassarão o periódico no periodo estudado, a saber: comemorar um passado em comum, noticiar temas ligados ao futuro da agricultura e afirmar a importância (no caso, o peso político) do distrito de Entre Rios para o presente do município de Guarapuava.

Cabe registrar que o Jornal de Entre Rios se identificava como um periódico voltado para a população suábia-danubiana das vilas que formam a localidade. Isso é explicitado em seu editorial de 1988, que afirmava ser seu objetivo principal "Divulgar os acontecimentos do distrito" e "conquistar de uma vez por todas a confiança [...] de nossos leitores, notadamente os moradores de Entre Rios." ${ }^{12}$ Reforçava também a intenção de ser o periódico voltado para a população do distrito o fato de sua tiragem ser de três mil exemplares por edição, pois esse número correspondia, aproximadamente, à população total de suábios do distrito na época (STEIN, 2011).

Ainda no ano de 1988 veio à tona um processo de profissionalização dos quadros técnicos e editoriais do periódico em nome da manutenção da periodicidade e do aprimoramento da qualidade gráfica. O editor chefe e responsável pelo jornal, Gonzaga Bezerra, que também atuava como editor de outros periódicos em Guarapuava e era proprietário da GeBe Representações e Negócios, sediada em Entre Rios, afirmava na edição que:

\footnotetext{
Para uma análise desses dois livros, ver: STEIN, 2011

JORNAL DE ENTRE RIOS. Entre Rios, Gebê Representações e Negócios, p.01, dez. 1986. Edição-teste. Os exemplares do jornal estão disponiveis para a consulta no Centro de Documentação da UNICENTRO e no Museu de Entre Rios, ambos no município de Guarapuava,

Paraná. Agradecemos aos seus funcionários pela atenção e pelo valioso auxilio na pesquisa.

11 Idem. Ibidem.

12 BEZERRA, Gonzaga. Estamos de Volta. Jornal de Entre Rios. Entre Rios, Gebê Representações e Negócios, n. 18 , p. 2, fev. 1988.
} 
[...] Após todas as avaliações e estudos feitos por nós, chegamos à conclusão de apenas mudar um pouco as dimensões do jornal (ele está atualmente com as colunas um pouco mais largas e, em conseqüência, aumentou poucos centímetros suas dimensões), modernizar gradativamente o visual interno, usando recursos gráficos não muito exagerados, enfim, fazer tudo de forma de não agredir de pronto os nossos leitores. ${ }^{13}$

Com um conselho editorial composto apenas por cooperados da Agrária e/ou membros de sua administração, o jornal parece estar fundado sobre um dilema. Buscava mudar e, ao mesmo tempo, permanecer o mesmo. Isso permite a problematização das formas de articulação entre o seu lugar de fala e as suas funções para essa comunidade. O jornal era inicialmente apoiado financeiramente pela Cooperativa Agrária, o que pode ser deduzido do agradecimento no editorial de fevereiro de 1988. A partir desse ano, o jornal passa a se identificar como parte do Sistema Entre Rios de Comunicação (rádio, jornal, TV) e como órgão da Fundação Pioneira de Rádio Difusão Educativa do Paraná, ${ }^{14}$ também sob auspícios da Cooperativa Agrária. Além disso, o periódico passa a ser publicado quinzenalmente. Posteriormente, associa-se à Associação Internacional de Meios de Comunicação em Língua Alemã (IADM) e à Federação dos Centros de Cultura Alemã no Brasil (FECAB). Em todo o período, o jornal disponibiliza espaços comerciais para publicidade de empresas privadas e públicas, o que também possibilitava a obtenção de recursos para o seu funcionamento. Destaca-se que, nos números comemorativos aos 40 anos de Entre Rios, a presença dos espaços comerciais é intensa e o tom das empresas anunciantes também assume a forma de congratulações aos feitos dos imigrantes.

Em seus primeiros números podem ser detectadas as caracteristicas da linha editorial do periódico. Nas seções temáticas sobre "História", "Memória" e "Comemorações", os textos abrangem tanto a colônia de Entre Rios e seus moradores quanto o passado remoto e recente da Europa, principalmente, acontecimentos que evolvem a Alemanha e a lugoslávia. Diante disso, a hipótese aqui desenvolvida é que o Jornal de Entre Rios reunia conteúdo e técnica para intervir na memória de um grupo, (in)formando o seu público com narrativas que interpenetravam temporalidades e técnicas agricolas com noções de identidade, articulando sentidos historicizados para a colonização e a superação do passado traumático da guerra.

Ao arquitetar representações identitárias e reorganizar fatos, fragmentados pela diagramação, o Jornal de Entre Rios formou uma opinião e um sentido para diferentes experiências de tempo reunidas naquele projeto de colonização agricola com refugiados da II Guerra Mundial. Nas edições de 1991 e 1992, voltadas para as extensas comemorações dos 40 da imigração para o Brasil, tais caracteristicas aparecem de forma intensificada. É o que abordaremos nas próximas páginas desse artigo.

\section{Expulsos da Terra Prometida: ${ }^{15}$ narrativas sobre o passado na Europa e a fundação de Entre Rios}

A edição comemorativa do jornal aos 40 anos de Entre Rios foi publicada em abril de 1991 e possui 48 páginas. Sua capa, composta por imagens e manchetes, indica um determinado sentido histórico que permeia a edição (Imagem 1). A imagem de fundo, que ocupa toda a página, é de uma fotografia aérea da sede da colônia, em que o destaque é a fábrica de malte cervejeiro da Cooperativa Agrária Agroindustrial. Na parte superior, à esquerda, há uma fotografia de uma mulher trabalhando na lavoura, seguida da seguinte frase escrita em português e alemão: "No início o trabalho foi duro". Trata-se de construir e cristalizar uma imagem do passado da localidade como fruto de um árduo trabalho coletivo. Abaixo está uma representação do presente, como sendo o resultado da intensa labuta dos suábios, constituida por uma fotografia que apresenta dois

\footnotetext{
13 Idem. Ibidem.

14 A Fundação Pioneira de Radiodifusão Educativa do Paraná é uma fundação de caráter privado de Guarapuava/PR, fundada em 25 de abr. 1983. Disponivel em: www.econodata.com.br/lista-empresas/PARANA/GUARAPUAVA/F/78282084000190-FUNDACAO-PIONEIRA-DE-RADIODIFUSAO-EDUCATIVA-DO-PARANA. Acesso em: 27 maio 2019.

15 SPADA, Odailson. Expulsos da Terra Prometida. Jornal de Entre Rios. Entre Rios, Sistema Entre Rios de Comunicação, n. 84, p. 8, abr. 1991.
} 
homens em meio a uma plantação de trigo e a frase: "Hoje é um exemplo para o Brasil!".

Imagem 1 - Capa da edição comemorativa do jornal aos 40 anos de Entre Rios

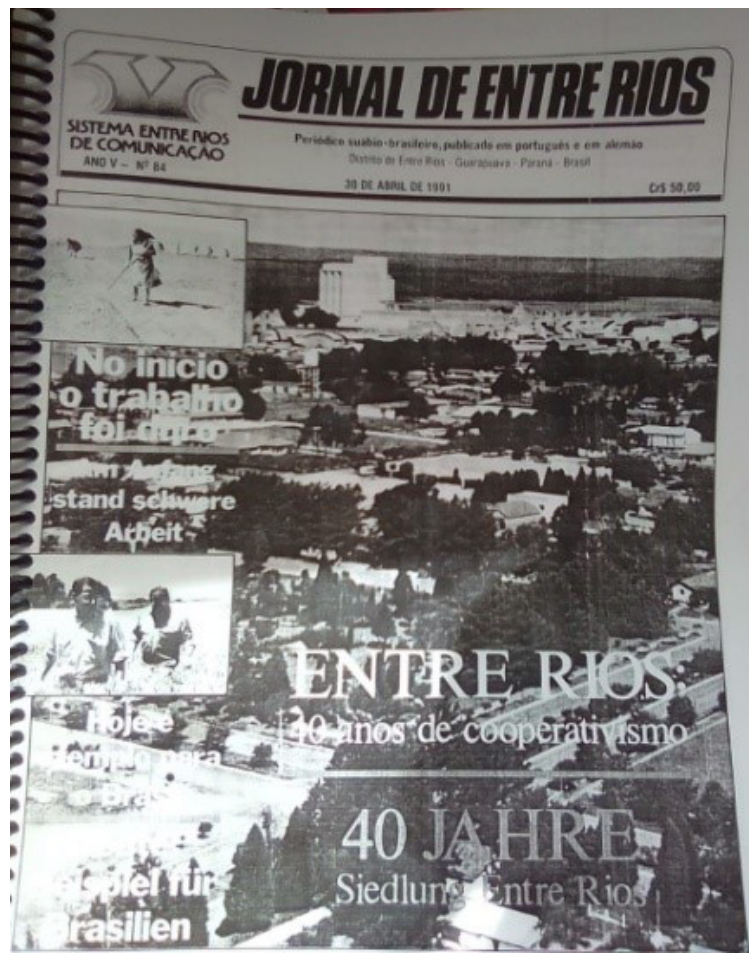

Fonte: Reprodução fotográfica realizada pelos autores da capa comemorativa do Jornal de Entre Rios, n. 84 . de 30 de abril de 1991. Disponivel para consulta no Centro de Documentação da UNICENTRO e no Museu de Entre Rios, Guarapuava, PR.

Após o editorial, em que os suábios são caracterizados como "um povo laborioso", há o artigo assinado por Mathias Leh, então presidente da Cooperativa Agrária. Como é de praxe nessas ocasiões, o tom do texto é de agradecimento aos membros da equipe que participou, no início da década de 1950, da escolha da localidade para a fixação dos suábios do Danúbio. Além disso, os suábios são constituídos como um sujeito coletivo de europeus que, no passado, encontravam-se "expulsos de sua terra" e para os quais "[...] foi oferecida uma nova existência, e eles deram à sua nova pátria, Guarapuava e arredores, impulsos econômicos que se projetam longe, no Brasil"16. Esse também é o tom da matéria sobre a fundação da colônia que, nas páginas seguintes, homenageia Michel Moor, primeiro presidente da Cooperativa Agrária e continua a enaltecer a importância da cooperativa para a economia da região e para o País.

Na oitava página encontra-se o texto intitulado "Expulsos da Terra Prometida", assinado pelo jornalista da Agrária, Odaílson Spada, que apresenta uma narrativa que constitui os sentidos acerca do passado do grupo na Europa. Vejamos:

Não foi fácil deixar a terra prometida. Mas a guerra não deixou outra alternativa. Eles haviam se estabelecido no rio Danúbio central, numa região que hoje faz parte da Hungria, Romênia e lugoslávia, constituindo uma minoria alemã entre húngaros e diversos grupos eslavos - e acabaram sendo expulsos de suas terras em meio aos movimentos comunistas e nacionalistas. ${ }^{17}$

A expressão "terra prometida" engloba tanto o tempo - um tempo sagrado que constitui o grupo em determinada época -, quanto um espaço geográfico, também sagrado. A expressão que vincula a terra ancestral dos suábios à narrativa biblica do Êxodo operava como instrumento de aglutinação do grupo, pois marcava, dessa forma, a sua origem e estava também presente no início dos três primeiros parágrafos do artigo. Nos dois primeiros, a narrativa tratava apenas da expulsão dos suábios desse espaço. O terceiro parágrafo, por sua vez, demarcava o tempo da chegada nesse espaço.

Cabe informar que o tema da expulsão dos povos de origem germânica na lugoslávia havia sido destaque anteriormente no jornal na edição de dezembro de 1988, que apresentava uma longa reportagem transcrita do jornal bávaro-suábio Augsburger Allgemeine do mesmo ano. O texto é assinado pelo Dr. Ortfried Kotzian, conhecido educador alemão, que naquele momento se dedicava à defesa dos direitos humanos e denunciara a perseguição, o êxodo e a execução da população suábia durante a II Guerra Mundial. O texto também apresenta fotografias de plantações ao lado de cemitérios na lugoslávia. No primeiro plano consta uma cruz quebrada, ao fundo a 
plantação e a legenda: "Sob a plantação de milho e batatas encontra-se o cemitério de Jarek. Era um campo de extermínio dos suábios".18

Além disso, retomando a edição de abril de 1991, percebe-se que o texto procura justificar o estabelecimento dos suábios na região, que viria a ser a lugoslávia, reafirmando e cristalizando uma imagem deles como agricultores e cristãos, garantindo a posse daquelas terras para a cristandade ocidental:

A história da terra prometida começou por volta do século XVII, quando os sucessores de Fernando I, o primeiro imperador austro-húngaro, detiveram a ofensiva turca, que chegou a Viena em 1683, mas não conseguiu subjugá-la. Os austriacos lançaram a contra ofensiva, ocupando a Transilvânia, em 1699, e o Banato de Timisoara, em 1719. Solidificando o poder, o império austro-húngaro sentiu necessidade de povoar a região conquistada com um povo de confiança, que pudesse garantir as fronteiras contra os turcos. A solução foi trazer agricultores dos paises alemães onde havia superpopulação.19

Na sequência, a desintegração do Império AustroHúngaro, um dos resultados da Primeira Guerra Mundial, é apresentada como o momento de início das perseguições aos suábios, o que teria obrigado muitos deles a vender as suas terras e a emigrar. Em seguida, os eventos relacionados à Segunda Guerra Mundial são apresentados da seguinte maneira:

Com a Segunda Guerra Mundial, no entanto, muitos participaram ativamente como soldados do "Reich", aumentando o antagonismo regional. No fim, com a ocupação comunista do leste europeu, foram simplesmente expulsos de suas terras. Muitos, inclusive, tiveram que fugir, para não serem mortos. ${ }^{20}$

A participação ativa de suábios no conflito é apresentada com a palavra Reich e não como Terceiro Reich. Tal estratégia narrativa sugere uma ligação genérica ao "império alemão" e não ao nazismo. O artigo finaliza com um parágrafo sobre a fuga para a Áustria e a Alemanha, onde passaram a viver em acampamentos provisórios, sem perspectiva de futuro, pois "[...] não sabiam o que fazer da vida". 21 A direção para um novo futuro, representado pela possibilidade de emigração para o Brasil, fornece uma sequência para a história dos suábios como um sujeito coletivo. Esse futuro vinha do auxilio de instituições suiças, especialmente a Ajuda Suiça à Europa, e da Organização das Nações Unidas.

A construção da narrativa a partir dos "sofrimentos suportados" pelo grupo pode ser compreendida através da reflexão de François Hartog sobre o lugar da testemunha na economia midiática do final do século $X X$. Para esse autor, a imprensa fornece "a referência para medir o horror, a bitola mediante a qual se avalia os crimes contra a humanidade [...]" (HARTOG, 2011, p. 209); pois que retoma a publicação das narrativas de testemunhas e de fotografias dos eventos por ocasião das suas comemorações: "Como se tivéssemos de passar por esses testemunhos de referência para nos convencermos da realidade e da gravidade de outros crimes" (HARTOG, 2011, p. 209).

A narrativa de testemunhas também estava presente no Jornal de Entre Rios e nesse sentido o processo de imigração para o Brasil e os primeiros anos de Entre Rios foram narrados como momentos de superação de dificuldades. Sob o título "Tempos dificeis", os jornalistas Odailson Spada e Ezil Schmitz apresentam a trajetória de Josef Kratz, um imigrante suábio, no período da fundação de Entre Rios, a saber:

Assim que chegaram, as primeiras dificuldades enfrentadas pelas familias foram com o clima e com a comida. Quando sairam da Europa era inverno e quando chegaram aqui era verão, todos sentiram a diferença. Com relação à alimentação, Josef Kratz lembra que era feita numa grande cozinha coletiva. "A comida era boa e forte, mas nós não estávamos acostumados".

Os primeiros tempos foram de muitas dificuldades. Muita gente ficava sem ocupação. Sem recursos, não havia como comprar maquinários básicos

\footnotetext{
KOTZIAN, Ortfried. Ein Tabu wurde gebrochen. Jornal de Entre Rios. Entre Rios, Sistema Entre Rios de Comunicação, n. 36, p. 10-11, dez. 1988. SPADA, Odailson. Expulsos da Terra Prometida. Jornal de Entre Rios. Entre Rios, Sistema Entre Rios de Comunicação, n. 84, p. 8, abr. 1991. SPADA, Odailson. Expulsos da Terra Prometida. Jornal de Entre Rios. Entre Rios, Sistema Entre Rios de Comunicação, n. 84, p. 8, abr. 1991. Idem. Ibidem
} 
para o trabalho. Na lavoura, a Agrária fazia quase tudo, com suas máquinas eles aravam e plantavam a terra. Para mudar essa situação, muitos homens e mulheres começaram a trabalhar fora. Vários foram para São Paulo onde se empregaram em casas de familias. Josef Kratz foi trabalhar em Guarapuava, numa indústria, e sua mulher como empregada doméstica. Assim, conseguiram guardar um pouco de dinheiro e comprar um cavalo e aos poucos os maquinários para o trabalho na lavoura. Foi assim que tudo começou. ${ }^{22}$

Percebe-se a construção de uma narrativa que trata o início da colonização como um tempo de dificuldades. Essa estratégia discursiva de ampliação do espaço do sofrimento no passado e caracterizá-lo como a gênese de Entre Rios potencializava o arco de trajetória de desenvolvimento alcançado pela população do distrito naquele presente (1991), justificando ainda mais a importância da comemoração. Também se percebe um silêncio do texto sobre cultivo em terras coletivas, organizado pela cooperativa ao início do processo de colonização (GOSSNER, 1952, p. 15; MICHELZ, 1989, p. 12) e, ao final, uma construção generificada do trabalho: o homem trabalhando em uma indústria e a mulher como doméstica.

Outro aspecto nesse fragmento da reportagem é uma narrativa que apontava para um futuro progressivo, de melhoria das condições de vida e de trabalho em Entre Rios. Embora mencione que um dos primeiros objetivos seria a aquisição de cavalos, o elemento que simboliza esse processo é o uso de máquinas no trabalho agricola. E a principal delas é o trator. É esse também o sentido da próxima matéria publicada, intitulada "Do Cavalo ao Trator" (Vom Ross zum Traktor), redigida em dialeto suábio (schwowe) e assinada por Anton Abt, um dos imigrantes suábios. Segundo Abt, na antiga pátria (alten Heimat) o trabalho na lavoura era realizado com uso de cavalos. Na comunidade em que vivia, havia uma máquina a vapor que era utilizada na colheita do trigo. Em Entre Rios, o trabalho começou com o uso de tratores. É essa experiência, com o primeiro trator, especialmente a dificuldade em aprender a dirigir a máquina, que ele narrava em um tom anedótico.

As páginas seguintes são dedicadas ao processo de imigração dos suábios para o Brasil - "Em busca da nova pátria" -, à constituição da Cooperativa Agrária e à transformação na região que resultou do estabelecimento dos suábios. Esse sentido é sintetizado por meio do seguinte texto do jornalista Paulo Esteche:

\begin{abstract}
Desde o dia em que um grupo de 500 familias se instalou em Entre Rios, há 40 anos, pelo menos esse território, com cerca de 900 quilômetros quadrados mudou radicalmente em suas características originais. A estepe de vegetação baixa, onde o gado era criado extensivamente, deu lugar a plantações de cinco culturas principais. Os casarões coloniais, das antigas fazendas foram substituidos por casas de arquitetura moderna, poucas lembrando o padrão europeu; ao invés de currais, erigiram-se armazéns graneleiros, inclusive uma indústria de grande porte - a Agromalte $\mathrm{S} / \mathrm{A}$, a maior maltaria da América Latina e uma das referências econômicas de Guarapuava. O municipio cresceu muito nesses últimos anos, mas nenhum núcleo habitacional teve um progresso tão homogêneo quanto Entre Rios. ${ }^{23}$
\end{abstract}

O fragmento também é um bom exemplo da regularidade em seus discursos no periodo estudado. As temáticas e as abordagens são repetitivas, apresentando narrativas estáveis e com papéis bem definidos para grupos humanos, etnias, gêneros e religiões.

\section{Desenvolvimento agrícola: o presente e as expectativas de futuro}

Como vimos na seção anterior do presente artigo, a denominada "antiga pátria" dos suábios do Danúbio na Europa é entendida como uma "terra prometida", a qual, por meio do trabalho, teria sido transformada em "celeiro da Europa". Entre Rios, por sua vez, passou a se constituir na "nova pátria" e, também, no "celeiro agrícola do Brasil". É esse o sentido do próximo texto do Jornal Entre Rios, intitulado '"O Velho Oeste' transforma-se num celeiro agrícola". Trata-se agora da constituição

\footnotetext{
SCHMITZ, Ezil; SPADA, Odailson. Tempos Dificeis. Jornal de Entre Rios. Entre Rios, Sistema Entre Rios de Comunicação, n. 84, p. 9, abr. 1991.

3 ESTECHE, Paulo. 40 Anos. Jornal de Entre Rios. Entre Rios, Sistema Entre Rios de Comunicação, n. 84, p. 18, abr. 1991.
} 
do passado e do espaço de Guarapuava, que teria sido transformado pelos suábios.

Acompanhando o texto do jornal, o qual está inserido ao lado de uma fotografia do embarque dos suábios em vagões que os levariam de Santos/SP para Guarapuava/PR, podemos mais uma vez lembrar Hartog quando discute o lugar do testemunho na história. Para o autor, o recurso às fotografias "[...] tem aumentado ao ponto de se tornar constitutiva de sua autenticidade e de sua verdade" (HARTOG, 2011, p. 209). Assim, a imagem do desembarque dos imigrantes portando apenas sua roupa do corpo e pequenas malas de mão, em oposição às imagens de prosperidade econômica no presente, vinha corroborar com o sentido histórico dado à narrativa do jornal. A saber:

A velocidade com que Entre Rios se desenvolveu, do início da colonização até hoje, domina a atenção de quem acompanhou o processo. O cooperativismo, como força-motriz da organização sócio-econômica, é visto como o 'segredo' do sucesso dos imigrantes, que se fecharam hermeticamente ao redor de um único propósito: resgatar a vida comunitária e próspera dos paises de origem, adaptando-se e melhorando as condições locais; por fim, construindo uma civilização sem perder os laços com o passado. Aos olhos de muitos habitantes, que vêem Entre Rios de fora, só as marcas do tempo podem explicar como os suábios, antes sem pátria, atingiram o estágio atual. ${ }^{24}$

No fragmento acima podemos notar que a constituição de uma nova historicidade para Guarapuava é marcada por dois aspectos. O primeiro é a velocidade. Ela acelera o tempo que destrói o "velho oeste", o passado da "nova pátria". O segundo aspecto é unidade dos suábios em torno da Cooperativa Agrária. Essa unidade opera em duas dimensões. Uma em direção ao futuro, acelerando e consolidando as transformações na paisagem e na economia guarapuavana, caracterizadas progressivamente por meio de estágios de desenvolvimento, e outra em direção ao passado. Mas não ao passado do "velho oeste" e, sim, o da "terra prometida" europeia, que era encarado como o modelo, como uma espécie de guia, uma inspiração para as ações do presente e do futuro.

Se a "terra prometida" estava consolidada como o espaço do passado que ancora a identidade coletiva dos suábios - uma identidade que se expressa em termos estáticos, pois os suábios mantêm no tempo as suas caracteristicas laboriosas, como vimos, por exemplo, na mensagem do ex-presidente da agrária, citada no início deste artigo -, o passado de Guarapuava era constituido como aquele que deveria ser o objeto de transformação, o "velho oeste" a ser superado.

Na sequência, a narrativa apresenta mais detalhes desse passado. Após o primeiro parágrafo, em que é mencionada a emoção expressada por uma moradora de Guarapuava ao relembrar que testemunhou a chegada dos suábios, a narrativa insere esse acontecimento em um quadro que envolve uma determinada representação sobre a história da região:

\begin{abstract}
A Guarapuava da época seguia o leito da História, já permeada por passagens de bravuras com o desbravamento da região, no século XIX. Uma nova página da História começaria a ser escrita a partir dali, do desembarque dos imigrantes, ilustrada pelo contraste de dois povos que o destino tratou de unir. Quem viu o acampamento montado na Vitória, sede de Entre Rios, compara o ambiente a um 'campo de guerra'. Para o suábio, a impressão inicial foi como se estivesse no 'faroeste', por causa dos chapelões e facões usados pelos guarapuavanos de então. ${ }^{25}$
\end{abstract}

Como podemos ler, tratava-se da constituição de duas temporalidades de Guarapuava. Uma delas caracterizada como um rompimento com um determinado passado congelado no século XIX que permaneceria o mesmo até meados do século XX. Em outros termos, embora a chegada dos primeiros suábios tenha acontecido no início da segunda metade do século XX, Guarapuava estava ali representada como uma paisagem do século XIX norte-americano, muito encontrada em filmes do gênero western. Essa seria a Guarapuava dos tempos pretéritos e que deixaria de existir,

24 ESTECHE, Paulo. O Velho Oeste Transforma-se num Celeiro Agricola. Jornal de Entre Rios. Entre Rios, Sistema Entre Rios de Comunicação, n. 84, p. 19, abr. 1991

25 Idem. Ibidem. 
dando lugar a um novo presente e a um novo futuro. Assim, a nova temporalidade guarapuavana iniciava a partir da constituição de uma imagem que lembrava uma paisagem pós-guerra, quando tudo está para ser construido; seria a gênese de um novo tempo, de uma história progressiva, de transformação da paisagem, do êxito econômico e da transformação da cultural local. Nesses dois momentos da história havia nas páginas do jornal um único sujeito: homens brancos europeus.

Ainda na sequência da edição comemorativa, sob o título "Capital da Madeira", o texto apresentava mais detalhes dessa história progressiva, marcada pelas mudanças nas maneiras de se extrair a riqueza da natureza:

Na década de 1950, os campos de Guarapuava estavam cobertos de matas e pastos nativos para o gado, que, ao lado da exploração da madeira, consistia na principal atividade econômica dos fazendeiros. Plantavam culturas de subsistência, como arroz, feijão e milho, mas sem nenhuma tecnologia. A derrubada das florestas, no entanto, trouxe muito dinheiro para a região, transformando-a na capital madeireira da América Latina, com 220 serrarias funcionando dia e noite.

Foi esse cenário que os imigrantes encontraram ao aportar na nova terra prometida, após viverem como refugiados de guerra na Áustria. ${ }^{26}$

Como podemos ler no fragmento anterior, a Guarapuava do passado era também constituída como um espaço em que a base econômica era a extração de madeira. A agricultura, que não tinha expressividade econômica na época, era caracterizada pela ausência de tecnologia. Esse cenário econômico fora transformado pela chegada dos suábios do Danúbio. Destaca-se aqui mais um silenciamento na narrativa, no que se refere à serraria que os próprios imigrantes suábios fundaram em Entre Rios. Essa, além de auxiliar na capitalização dos colonos, também atraiu trabalhadores locais para as colônias em questão (FROTSCHER; STEIN; OLINTO, 2014).

Após enfatizar a boa relação entre os guarapuavanos e os suábios, a narrativa novamente constituia um quadro que enaltecia o protagonismo destes últimos na transformação de Guarapuava em uma civilização:

Guarapuava tornou-se o berço desta civilização de agricultores, que arquivaria em definitivo o terror da guerra e passaria a viver em meio à prosperidade. modificando planícies de pecuária em extensas áreas de lavouras. Do linguajar caboclo do nativo, Entre Rios viria a conviver com o dialeto suábio. Os campos foram rasgados pelos arados e o verde do trigo e do arroz não demorou para brotar do chão ácido e virgem, que levou a muitos estudos e também a perdas na colheita, enquanto não se descobriu a técnica e época ideais para plantio. ${ }^{27}$

Tratava-se de um novo cenário construído pelos suábios do Danúbio. O passado da guerra foi retirado da pauta. Do que existia na nova pátria, tudo fora modificado: os chapelões e os facões desaparecem, o pasto do gado dá lugar às lavouras, o solo foi corrigido, a linguagem do caboclo substituida pela linguagem do recémchegado e o vaqueiro pelo agricultor. Essa região, antes conhecida como "O Velho Oeste", havia se tornando civilizada por meio de imigrantes e da tecnologia. É ela - a tecnologia - e o seu uso, cabe ressaltar, o principal instrumento que produzia a diferença entre as gentes e as suas histórias.

A narrativa segue na página seguinte do jornal com a citação da fala de Antônio Lustosa, exdeputado estadual e um dos fazendeiros que teve as suas terras desapropriadas e indenizadas quando da fundação de Entre Rios. Ao lado de um quadro com entrevistas de suábios que optaram por viver na cidade de Guarapuava, a narrativa de Lustosa enfoca a substituição da pecuária pelo desenvolvimento da agricultura. A expressão "seiva revigorante", inserida abaixo de sua fotografia, sintetiza esse sentido de circulação e vida ligada à agricultura capitalista.

O texto também apresenta mais elementos que produzem uma imagem de rompimento com o passado de Guarapuava. Trata-se da narrativa em que a principal personagem é uma 
moradora da região que vivia como agregada em uma das fazendas desapropriadas: Maria Gomes de Carvalho, conhecida como Maria Tiriri. O título do texto, "Morador nativo sofre impacto da colonização", indicava o seu lugar nesse processo: o de agente passivo, que simboliza as gentes do passado da localidade. Essa caracteristica abarca não somente o momento da chegada dos suábios, mas engloba também o futuro - aqui expresso pelo termo "destino". Vejamos um fragmento do texto: "A colonização não provocou mudanças somente na vida dos suábios. Para os moradores nativos, agregados dos fazendeiros, também foi uma alteração de rota, porque o destino deles estava colocado nas mãos dos novos habitantes".28

Os termos "rota" e "destino" definem os protagonistas, os agentes ativos- no caso, os suábios do Danúbio - e os passivos - as outras gentes, a população local, os nativos, os agregados das fazendas, ou seja, aqueles que sofreram o impacto dos protagonistas da história. O papel dos não suábios, inclusive como narradores - pois a fala de Maria Gomes de Carvalho enfoca somente o passado - marcava a diferença entre passado e presente e cristaliza o seu lugar no pretérito. Já os suábios do Danúbio, cabe ressaltar, seriam os que manejavam e determinavam o sentido da história, cujo destino seria o progressivo e o acelerado aumento da produção agrícola. Ou seja, não se trata de um destino final, mas de um futuro continuo.

Em seguida, após informar que parte de agregados das fazendas fora trabalhar como empregados na Cooperativa Agrária apresentavamse mais aspectos que legitimavam a presença e a transferência das terras para os recém-chegados:

Quem não ficou em Entre Rios teve como opção uma lei assinada pelo governador Bento Munhoz da Rocha, que concedia dez alqueires para cada agregado chefe de família na encosta do rio Piquiri, divisa com o municipio de Pitanga. "A terra era boa inclusive para café, mas a maioria vendeu", reclama o jornalista Antônio Lustosa de Oliveira, na época deputado estadual e autor do projeto. ${ }^{29}$
Portanto, quanto aos que saíram de Entre Rios, mesmo recebendo uma porção de terras, o destino nos é desconhecido. Para o jornal, não tiveram a capacidade de construir um futuro, pelo menos um futuro como proprietários de terras. Em outros termos, o futuro pertencia aos suábios, pois seriam os detentores do conhecimento e da tradição para alcançarem o sucesso na produção agricola. O paradeiro dos antigos agregados que sairam da colônia é incógnito; para eles não há presente e nem futuro, só passado.

A referida matéria ainda permite perceber mais dois aspectos que demarcavam os sujeitos do passado, do presente e do futuro da região. O primeiro refere-se às gerações dos suábios. Novamente temos a citação de um fragmento de Maria Tiriri, que "[...] considera os imigrantes pessoas trabalhadoras, dizendo que gostava de ajudá-los, limpando o campo e amontoando o feno, 'tudo no muque'". E acrescenta: "Agora até que não trabalham muito; já têm tudo."30 $\mathrm{O}$ segundo aspecto envolve, novamente, o uso de máquinas, como é possivel ler nas linhas finais do redator do texto:

Entre Rios ainda conserva resquícios da Guarapuava antiga. Não é dificil ver, diariamente, um cavaleiro percorrendo as ruas da Vitória, carregando mantimentos para a semana. Do outro lado, o agricultor com seu trator completa a paisagem de Entre Rios contemporânea. ${ }^{31}$

Nos fragmentos anteriores podemos perceber, de forma sintética, a constituição de temporalidades e de seus sujeitos. Do passado, ou do "velho oeste" guarapuavano, há somente "resquicios", alguns vestígios. Maria Gomes de Carvalho, a Maria Tiriri, é a sintese desse passado, do trabalho sem tecnologia. É uma idosa, cujo incontornável destino é desaparecer em breve. Outro "resquício" é o cavaleiro anônimo, de quem não há a necessidade de informar o nome e nem qual seria a profissão, mas apenas mencionar que se trata de um modesto consumidor, o da

\footnotetext{
JORNAL DE ENTRE RIOS. Entre Rios, Sistema Entre Rios de Comunicação, n. 84, p. 22, 30 abr. 1991

Idem. Ibidem

Idem. Ibidem.

Idem. Ibidem
} 
subsistência semanal - o que indica o futuro curto como horizonte de suas preocupações. Do outro lado, ou em outra temporalidade. estão, novamente, o agricultor e o trator. São os construtores do celeiro agrícola em Guarapuava. O tempo presente e o futuro a eles pertencem.

As páginas finais da edição comemorativa consolidam esse sentido que enaltece e legitima a criação de Entre Rios. No texto intitulado "Valeu a Pena", temos, no primeiro parágrafo, uma narrativa dos suábios do Danúbio refugiados na Áustria em condições de carestia. A oportunidade para emigrar para o Brasilé caracterizada como "[...] uma esperança de um recomeço para quem está sem pátria, sem futuro e sem esperanças". O texto é finalizado com a resposta à pergunta "Valeu a pena?":

\begin{abstract}
A resposta é muito clara, pois as pessoas que para cá vieram à procura de um futuro melhor encontraram aqui não só um país, mas também um povo que os acolheu como irmãos. Valendo-se das oportunidades que se lhes oferecia, construiram com seu trabalho e sacrificio não somente a sobrevivência, mas também uma situação estável. Encontraram aqui tudo o que thes carecia: comida, habitação, trabalho e pátria. ${ }^{32}$
\end{abstract}

O texto seguinte, em língua alemã, apresenta elementos que consolidam o êxito dos suábios do Danúbio. Intitulado "Quarenta Anos de Progresso" (Vierzig Jahre Fortschritt), apresenta números da produção de cereais - 277.338 toneladas de soja, milho, aveia, cevada, trigo e arroz que foram colhidos em 63 mil hectares. Ao final do texto temos a citação de uma fala do então prefeito de Guarapuava, Fernando Ribas Carli, que constitui os suábios como exemplos para os agricultores guarapuavanos: "Eles nos ensinaram a cultivar nossas terras" ("Sie haben uns gelehrt, unser Land anzubauen"). É esse também o tom do texto que encerra a edição comemorativa, que caracteriza a Cooperativa Agrária como modelo para outras cooperativas do Brasil, o que nos lembra as fotografias e as narrativas da capa da edição comemorativa, descrita no início deste artigo.

\section{0 presente estendido: uma comemoração monumento}

Se as edições de 1991 abriram as comemorações dos 40 anos de Entre Rios narrando temporalidades: passado, presente e futuro, os números publicados em 1992 encerram tais festividades divulgando registros fotográficos detalhados dessas comemorações. Além da manutenção da mesma discursividade organizadora de tempos e sujeitos já apresentada, a repetição dos discursos, agora ilustrados, apresentava-se como uma vontade editorial de monumentalização do presente visando preservá-lo ou expandi-lo ao futuro.

Na edição de número 101, de 13 de janeiro de 1992, na seção de carta ao leitor, o editor do jornal lembra os "40 anos de realizações da colonização" e justifica a duração das festividades de aniversário de Entre Rios, que estavam ocorrendo há um ano pelo menos, segundo as páginas do jornal. Para isso, o articulista lembra que a vinda dos imigrantes se dera de forma parcelada e que o último grupo só havia chegado em Guarapuava no agosto de 1952, daí a duração da festa. O editorial também repercute o tom encontrado na narrativa das festividades e de seu desfile comemorativo, ao buscar resolver o problema do encontro entre os suábios e os brasileiros promovido por essa colonização, assim: "Hoje apresentam o progresso de Entre Rios como forma de agradecer a acolhida por parte dos brasileiros."33

O brasileiro tornava-se o personagem acolhedor nas páginas do jornal. Tal discursividade é novamente apresentada nas falas dos políticos locais. Tanto o prefeito de Guarapuava, Ribas Carli, quanto seu principal oponente político no periodo, César Silvestre, publicaram as suas respectivas cartas abertas de congratulações pelo aniversário da colonização. O primeiro destaca, no título, o "Exemplo de trabalho", e o segundo afirma "Reconhecendo o trabalho pioneiro". Novamente o trabalho é a característica identitária a-histórica do grupo de refugiados. O tom festivo continua na edição seguinte, número 102, de 21 do mesmo 
mês, na qual a manchete é "Suábios do Danúbio do mundo participaram da festa". A importância da comemoração no presente deve ser fixada também pelo periódico, como podemos ver na Imagem 2.

Imagem 2 - Capa do Jornal de Entre Rios de 31 de janeiro de 1992

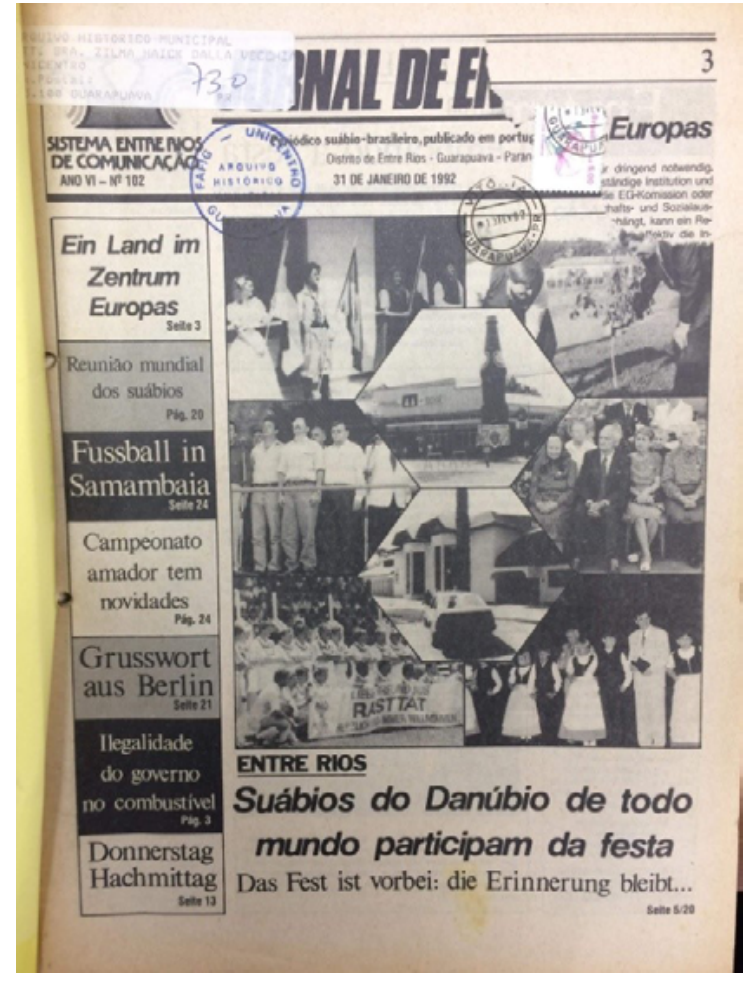

Fonte: Reprodução fotográfica realizada pelos autores da capa comemorativa do Jornal de Entre Rios, n. 102, de 31 de janeiro de 1992. Disponivel para consulta no Centro de Documentação da UNICENTRO e no Museu de Entre Rios, Guarapuava, PR.

Nessa edição, o desfile, denominado "Desfile Histórico", apresenta, por meio de fotografias e de textos, a teatralização das diferenças e dos papéis dos grupos na Europa e em Guarapuava. ${ }^{34}$ Os personagens, previamente definidos, são representados ao reconhecimento público: os suábios como um grupo coeso e visto pelo viés da vitimização, pelo sofrimento da guerra e do refúgio; 35 os comunistas são denominados como "terroristas", os perpetuadores das injustiças; e os brasileiros descritos como "acolhedores", aos quais cabe o papel de anfitriões nas novas terras, anfitriões agradecidos, porém incapazes ao trabalho, afinal, antes da chegada dos imigrantes: "Entre Rios era apenas um aglomerado de fazendas de gado"36. É o que podemos ver na página reproduzida na Imagem 3.

Imagem 3 - Fotografias do "Desfile Histórico"

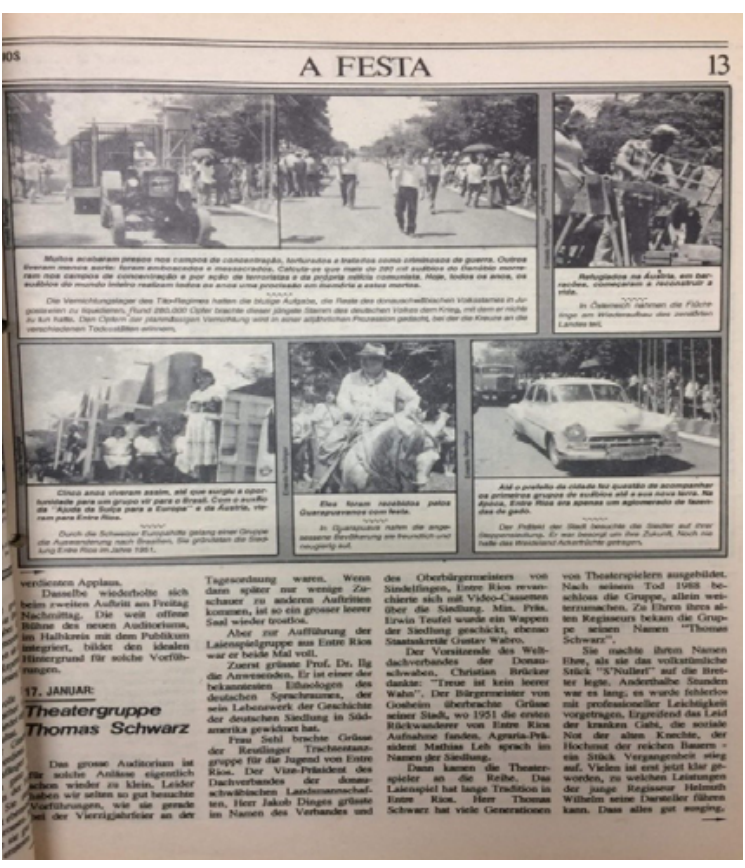

Fonte: Reprodução fotográfica realizada pelos autores da página 13 do Jornal de Entre Rios, n. 102, de 31 de janeiro de 1992. Disponivel para consulta no Centro de Documentação da UNICENTRO e no Museu de Entre Rios, Guarapuava, PR.

Percebe-se nas narrativas do jornal um esforço em construir uma história coesa e de fácil compreensão, porém ao tratar de tantos eventos traumáticos e complexos acabam por sintetizá-los em historicidades distintas. A problemática da tradução dos sofrimentos humanos para uma linguagem adequada aos princípios contemporâneos dos Direitos Humanos e o seu "vocabulário restrito" foi abordada por Rebecca Saunders ao analisar os trabalhos da

\footnotetext{
34 Para uma análise minuciosa sobre a reportagem e o desfile comemorativo na construção da memória coletiva suábia ver: LERMEN, 2019 35 François Hartog analisa essa espécie de competição pelo reconhecimento público dos sofrimentos suportados como uma competição vitimária na qual se embasa um denominador comum para a identidade de grupo. Ver: HARTOG, 2011, p. 209.

36 JORNAL DE ENTRE RIOS. Entre Rios, Sistema Entre Rios de Comunicação, n. 102, p. 13, jan. 1992.
} 
Comissão de Verdade e Reconciliação as África do Sul (SAUNDERS, 2008). Ao dialogarmos com as reflexões da autora, encontramos nas narrativas da comemoração da colonização suábia no Paraná, características similares como: construir grupos humanos estáticos e homogeneizados, papéis pré-definidos (o de vítima, de perpetuador ou testemunha) e uma classificação restritiva da legitimidade das experiências de sofrimento, tudo em nome de uma reconciliação de um corpo político nacional. Em Entre Rios a construção era de uma identidade coletiva exemplar e desejável para Guarapuava, como também para o estado do Paraná e, quiçá, para o Brasil (OLINTO; STEIN, 2019).

A importância da aceitação promovida pelos brasileiros e, principalmente, pelas autoridades locais, dessa imigração é constantemente reforçada. Tanto reforçada no desfile, ocasião em que o prefeito da época da imigração foi representado, quanto nas páginas do jornal, nas quais os políticos locais apresentam as suas congratulações ao grupo de imigrantes.

O desfile teatralizou as noções, também apresentadas nas páginas do jornal, de que o trabalho e o pioneirismo vinham de fora, dos europeus. As populações trabalhadoras locais nunca são exemplos, nem de trabalho, nem de ocupação e uso da terra. O passado local era visto como dormência de qualquer potencial de futuro; o trabalho não era uma característica ontológica do ser humano, e sim um dado seletivo, apenas alguns grupos eram tidos como aptos para ele. E só a chegada dos imigrantes fora capaz de despertar a potência daquele aglomerado de terras guarapuavanas.

Na edição de 8 de junho do mesmo ano, a última a tratar das comemorações dos 40 anos, a manchete informava: "Um registro da festa para a posteridade". Nela, uma vontade de memória é confessada, pois que ela se propõe logo na capa em cores, a ser um "Documento", conforme a Imagem 4.
Imagem 4 - Capa da edição especial sobre as comemorações dos 40 anos de Entre Rios

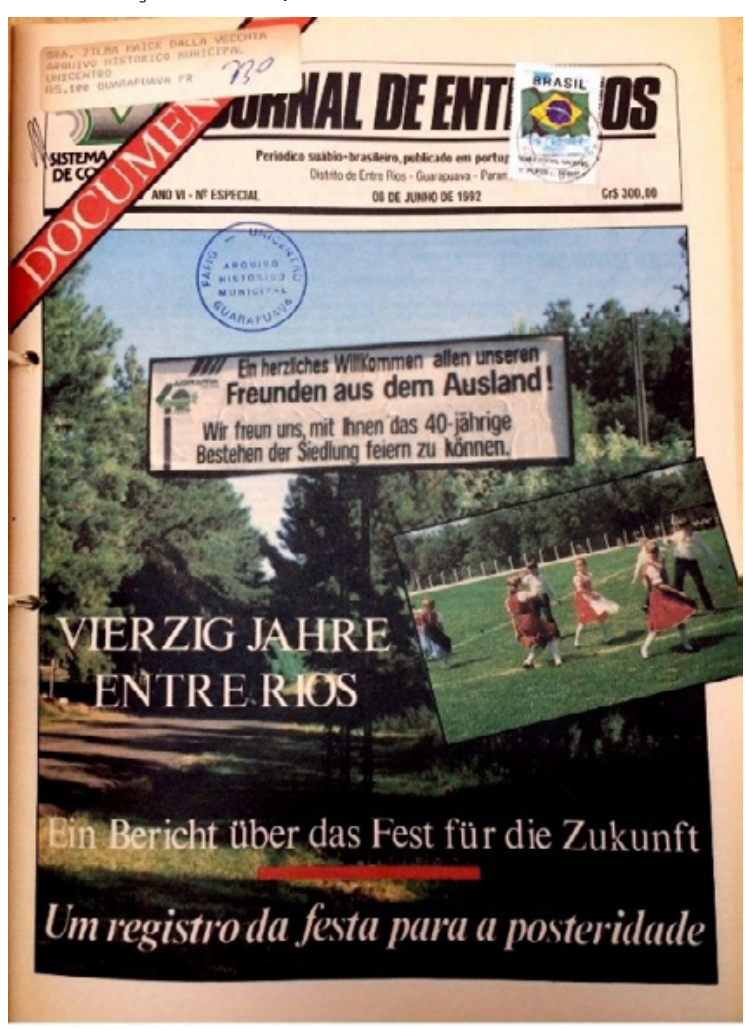

Fonte: Reprodução fotográfica realizada pelos autores da capa do Jornal de Entre Rios, de 8 de junho de 1992. Disponivel para consulta no Centro de Documentação da UNICENTRO

A manchete da edição especial saúda os "Quarenta anos Entre Rios". Tal texto está sobreposto a uma fotografia em perspectiva de uma estrada em meio a uma mata e, ao seu lado, há outra foto que mostra um grupo de jovens dançando e trajando roupas folclóricas em um campo de futebol (Imagem 3), o que pode ser deduzido pelas marcações sobre o gramado. Na placa em cima da estrada pode ser lido em alemão: "Uma calorosa recepção a todos os nossos amigos do exterior! Estamos felizes em celebrar com vocês os 40 anos da colônia."37.

Na segunda página, o jornal apresenta algumas cartas de congratulações recebidas pela comissão organizadora da festa e pela Cooperativa Agrária. Essa seção é intitulada "Diálogos" e se estende por várias páginas do periódico. Chama nossa atenção que todas as 
cartas transcritas são publicadas somente em lingua alemã, o que limita o diálogo aos versados nesse idioma, ou seja, aos suábios e aos alemães.

Nas páginas seguintes são apresentados visitantes vindos de Rastatt, cidade alemã coirmã de Entre Rios, e as cerimônias de renomeação de ruas e de lugares nas colônias em homenagem aos fundadores de Entre Rios. Nesse momento, é ressaltado pelo jornal que Entre Rios "[...] é a colonização alemã mais recente do Brasil."38 Conforme o estudo de Stein (2011), a opção da Cooperativa Agrária foi e é pela construção de uma identidade germanizada para a colônia de Entre Rios. Tal estratégia identitária reaparece no periódico constantemente e esse tem clareza sobre ela: "O estabelecimento da cultura bilingue promovida pela Cooperativa Agrária é, aliás, uma estratégia para que os suábios possam continuar preservando o idioma que herdaram dos antepassados [...]",39

Na sequência, a edição apresenta a manchete intitulada "Numa enxurrada de emoções". No texto, sob essa manchete, a edição especial busca mostrar a alegria dos suábios em receber os visitantes. Esse sentido é reforçado por meio de uma fotografia da placa de boas-vindas colocada na entrada da vila Samambaia de Entre Rios. Com a inscrição "Aqui, há 40 anos você é bem-vindo, comemore com a gente." 400 texto da referida placa também foi reproduzido em negrito e caixa alta na abertura da reportagem intitulada "O convite para a comemoração dos 40 anos". O capricho da estratégia bilingue parece não ser o mesmo para ambas as linguas, porém a organização temporal e das emoções citadas pela manchete logo são descritas e ligadas entre si pelos discursos proferidos nas festividades: "Alguns emocionados, outros nostálgicos recordando o passado, elogiando o presente e prevendo o futuro."41

Poucas páginas à frente há um texto bilingue escrito por Mathias Leh, o presidente da Cooperativa Agrária. Além de agradecer a todos os que trabalharam no evento, o autor também justifica as motivações para a publicação daquela edição especial do periódico, a saber:

Um monumento aos suábios do Danúbio

O leitor talvez se surpreenda ao pegar esta edição especial do Jornal de Entre Rios, já que entrementes tanto se escreveu e se relatou a respeito dos 40 anos da fundação de Entre Rios. [...] foram diversos os motivos [...]. A consciência de que a geração dos pioneiros, fundadores da colônia está desaparecendo [...], outro motivo foi com vistas à juventude [...], levar a eles as lembranças da emigração e da história dos suábios do Danúbio. ${ }^{42}$

Trata-se de um monumento que fixa o tempo e expande aquele momento fugaz ao futuro. A própria duração das festividades aponta para essa intenção monumental e duradoura. Lembrando as reflexões de François Hartog, podemos entender esse prolongamento do presente em direção ao futuro como indício de uma crise da temporalidade no mundo contemporâneo. Dai essa necessidade de fixar o tempo, de conter a sua vertigem e fluidez (HARTOG, 2015, p. 258). Tal motivação é confessada nos fragmentos do discurso de Mathias Leh citados acima, nos quais também se pode apontar o local de fala do presidente da cooperativa ao chamar o deslocamento dos suábios para o Brasil de "Emigração" - pois Leh falava de um ponto de vista europeu.

Trata-se, destarte, de um passado lembrado em demasia e de um presente como promessa consumada e projetado para o futuro como permanência. Assim, um espaço de experiência traumática era superado pela narrativa de um passado grandioso e sagrado para o grupo. As narrativas do Jornal de Entre Rios buscavam resolver a tensão entre o passado e o futuro por meio da construção de uma imagem de contínuo sucesso para o presente. O futuro abria-se, então, como permanência desse presente de felicidade e de prosperidade centrado em noções como a

\footnotetext{
JORNAL DE ENTRE RIOS. Entre Rios. Entre Rios, Sistema Entre Rios de Comunicação, p. 3, 8 jun. 1992. Edição especial. 
de progresso e de trabalho. Diante disso, cabe citar novamente as seguintes reflexões de Hartog sobre os regimes de historicidade:

Estendido e mesmo interminável (o que faz justamente que o passado não passe), nosso presente não é só isso. Existe uma variedade de 'tempo que dura', aquele traumatismo, o que habita os sobreviventes dos campos de concentração e que, em certos momentos, ressurge (HARTOG, 2015, p. 259).

Ainda há no jornal uma descrição pormenorizada de todas as atividades comemorativas e dos nomes de todos os envolvidos. Essa preocupação do periódico em não esquecer nenhum nome, nenhuma atividade, fossem bailes, procissões, missas, almoços, reuniões dos representantes das associações suábias, reformas no hospital da colônia e inaugurações, representam bem essa intenção documental da comemoração dos 40 anos e poderia ser interrogada como parte de uma "[...] tendência de historicização imediata do presente, que reconhecemos como um traço de época" (HARTOG, 2015, p. 247). Destacam-se aqui, entre as inaugurações, a do Museu Histórico e a do Centro Cultural, ${ }^{43}$ pois que essas podem ser compreendidas como parte da mesma estratégia da edição especial "Documento", do Jornal de Entre Rios.

Finalmente, mas não menos importante, encontra-se, nas páginas do jornal, mais uma vez a relação entre o "velho oeste" e a "terra prometida", a relação entre os imigrantes e os habitantes locais anteriores. Essa relação é retomada no espaço da seção "Habitação" no Jornal. Nela é noticiada a inauguração de um conjunto habitacional: "Na medida que a cooperativa agrária e as suas organizações vão expandindo suas atividades e criando novos empregos, o problema da falta de moradia em Entre Rios vai se tornando crítico." 44 Destaca-se que a Cooperativa é apresentada como o agente do desenvolvimento econômico, apesar de que o valor dos salários pagos a esses empregados não viabilizava a aquisição autônoma de moradias, pois que, segundo a reportagem, fora a Agrária que financiara a construção em parceria com a Comunidade Econômica Europeia e a Agência para Desenvolvimento da Baviera. Pode ser observada, nessa reportagem, a construção de uma dicotomia invertida entre quem eram os moradores locais e quem eram os estrangeiros naquelas terras. Estes últimos não eram mais os refugiados de guerra, e sim os moradores da região, os quais procuravam emprego e um lugar, uma terra onde viver. Os moradores mais recentes, os suábios, apareciam agora como os nativos do local e a população brasileira era reapresentada como a forasteira. Não era à toa que o nome escolhido para o conjunto habitacional fosse "Europa." 45

\section{Considerações finais}

"Erfolg heute, morgen und immer mehr!"46

As festividades alusivas aos 40 anos de Entre Rios ocorreram entre 1991 e 1992, período no qual François Hartog se perguntava se estaríamos passando por uma crise do tempo e por uma organização de um novo regime de historicidade. A hipótese seria a de um regime presentista, ou seja, um presente percebido de forma expandida por sobre o passado e o futuro. Tal regime de historicidade reduziria não só o espaço de experiência (passado no presente), mas também o horizonte de expectativa (futuro no presente), acompanhando as categorias de Reinhart Koselleck (2006, p. 309-310). Nesse sentido, o presenteteria uma dupla divida tanto realizar os sonhos passados e quanto se projetar sobre qualquer ideal de futuro, suplantando quaisquer utopias, vistas, então, como fracassadas

Ademais, o Jornal de Entre Rios também promovia uma "duplicata do mundo" (LUCA,

\footnotetext{
43 Sobre a constituição da identidade cultural das colônias de Entre Rios, ver STEIN, 2011.

44 SCHMITZ, Ezil. Conjuntos habitacionais trazem mais conforto aos moradores de Entre Rios. Jornal de Entre Rios. Entre Rios, Sistema Entre Rios de Comunicação, p. 34, 8 jun. 1992. Edição especial.

45 Idem. Ibidem.

46 Sucesso hoje, amanhã e sempre mais! (Tradução nossa). JORNAL DE ENTRE RIOS. Entre Rios, Sistema Entre Rios de Comunicação, p. 45, 8 jun. 1992. Edição especial.
} 
2008, p. 132), trazendo à vida eventos distantes, que, uma vez vividos pela leitura, passam a compor um sentido para uma identidade. A expressão "duplicata do mundo" construiria sentido, pois tais papéis identitários seriam fixados ao serem nomeados. Então, a "terra prometida" e o "velho oeste" seriam endereços fixos de pertencimento para a identidade do grupo, bem como as noções de progresso e o atraso, a realização e o fracasso, entrelaçados a eles.

Nas páginas analisadas do periódico, as narrativas elaboravam relações do presente com o passado e o futuro. Nesse sentido, cabe novamente lembrar as reflexões de François Hartog acerca da noção de um regime de historicidade entendido como forma de "[...] engrenar passado, presente e futuro ou de compor um misto das três categorias, [...]" (HARTOG, 2015. p. 11). Portanto, os elementos discursivos constitutivos dessas narrativas organizadas nas páginas do Jornal de Entre Rios criavam um espaço de divulgação e legitimação de uma ordenação das temporalidades que buscava abolir a distância entre o passado, o presente e o futuro, difundindo assim um regime de historicidade. Eram narrativas elaboradas em um presente, com vistas a perpetuálo; uma permanência de sentidos que relacionava e cristalizava a capacidade para o trabalho e para o progresso econômico como características identitárias de um grupo, os suábios do Danúbio, e não de outro.

\section{Referências}

CASAGRANDE, Thomas. Die Volksdeutschen SS-Division "Prinz Eugen". Die Banater Schwaben und die National-Socialistischen Kriegsverbrechen. Frankfurt: Campus Verlag, 2001.

COOPERATIVA AGRÁRIA MISTA ENTRE RIOS LTDA. Documentário Ilustrado da Colonização Suábio-Danubiana Campinas, SP: Cartgraf, 1976.

ELFES, Albert. Suábios no Paraná. Curitiba, PR: [s. n.], 1971

FERNANDES, Márcio; HORST, Sheila Joanne; GIORDANI, Renatha. 100 anos de imprensa em Guarapuava: veículos, circulação e personagens. Disponivel em: http://repositorio.unicentro.br:8080/jspui/bitstream/123456789/1248/29/FERNANDES\%2C\%20 HOSRT $\% 20 \% 26 \% 20$ GIORDANI\%20-\%20100\%20Anos\%20 de\%20Imprensa\%20em\%20Guarapuava.pdf.Acesso em: 27 maio 2019.
FRÖSCH, Max. Guarapuava: Die Donauschwäbische Flüchtlings-Siedlung in Brasilien. Freilassig: Pannonia Verlag, 1958.

FROTSCHER, Méri; STEIN, Marcos Nestor. "E estava tudo bem até começar a guerra": sofrimentos e ressentimentos em narrativas orais de uma refugiada da II Guerra Mundial no Brasil. In: WADI, Yonissa (org.). Narrativas sobre loucuras, sofrimentos e traumas. Curitiba, PR: Máquina de Escrever, 2016. p. 175-202.

FROTSCHER, Méri; STEIN, Marcos Nestor; OLINTO, Beatriz Anselmo. Memória, ressentimento e politização do trauma: narrativas da II Guerra Mundial (Suábios do Danúbio de Entre Rios, Guarapuava-PR). Revista Tempo, Rio de Janeiro, v. 20, p. 1-26, 2014. https://doi.org/10.20509/ TEM-1980-542X2014V203620.

FROTSCHER, Méri; STEIN, Marcos Nestor; OLINTO, Beatriz Anselmo. "Eles também não tinham nada": narrativas orais de deslocamentos e encontros identitários em Entre Rios (Guarapuava - PR). Diálogos, Maringá, v. 8, n. 13, p. 1039-1067, set./dez. 2014

GOSSNER, Walter. Die Siedlung der Donauschwaben im Municip Guarapuava im brasilianischen Staate Paraná Bericht über die Ergebnisse der im Auftrage der Schweizer Europahilfe durchgeführten Untersuchung. Jundiai: März 1952. Mimeo.

HARTOG, François. Evidência da história: o que os historiadores veem. Belo Horizonte, MG: Autêntica, 2011.

HARTOG, François. Regimes de historicidade: presentismo e experiências do tempo. Belo Horizonte, MG: Autêntica, 2015.

JORNAL DE ENTRE RIOS. Entre Rios, Gebê Representações e Negócios. 1986-1988.

JORNAL DE ENTRE RIOS. Entre Rios, Sistema Entre Rios de Comunicação. 1988-1993.

KOSELLECK, Reinhart. Futuro passado: contribuição à semântica dos tempos históricos. Rio de Janeiro: Contraponto/PUC, 2009 .

LERMEN, Nathan Henrique da Silva. "Rostos apátridas": uma leitura da memória suábia através de seus periódicos comemorativos. Relatório Final de Iniciação Científica. (Graduação em História), UNICENTRO, 2019.

LUCA, Tânia R. de. A Revista do Brasil (1916-1944): notas de pesquisa. In: FERREIRA, Antônio Celso; BEZERRA, Holien Gonçalves; LUCA, Tânia Regina de. O historiadore seu tempo. São Paulo: UNESP/ ANPUH, 2008. p. 117-138.

MICHELZ, Johana Elisabeth. Campesinato X Agricultura Capitalista em Entre Rios: 1951-1985. Monografia (Especialização em História econômica do Brasil) Guarapuava: Fundação Faculdade Estadual de Filosofia, Ciências e Letras de Guarapuava. 1989.

OLINTO, Beatriz Anselmo; FROTSCHER, Méri. Narrativas de sofrimento, narrativas de firmação: reflexões sobre a autobiografia de uma refugiada da II Guerra Mundial. In: WADI, Yonissa. (org.). Narrativas sobre loucuras, sofrimentos e traumas. Curitiba, PR: Máquina de Escrever, 2016. p. 203-222. 
OLINTO, Beatriz Anselmo; STEIN, Marcos Nestor. "Um resumo do Brasil": diferença e historicidade na construção do rural no Paraná. Topoi (Rio J.), Rio de Janeiro, v. 20, n. 42, p. 751-774. Set. 2019. Disponivel em: http://www.scielo.br/scielo.php?script=sci_arttext\&pid=S2237-101X2019000300751\&lng=en\&nrm=iso. Acesso em 30 Jan. 2020. https://doi.org/10.1590/ 2237-101×02004210.

SAUNDERS, Rebecca. Sobre o intraduzivel; sofrimento humano, a linguagem de Direitos Humanos e a Comissão de Verdade e Reconciliação da África do Sul. SUR Revista Internacional de Direitos Humanos, São Paulo, Ano 5, n. 9, p. 52-75, dez. 2008. https://doi.org/10.1590/ S1806-64452008000200004.

SCHERER, Anton. Seit 42 Jahren heißen wir Donauschwaben. In: Volkskalender 1964. Ein Jahrbuch des Gesamten Donauschwabentums. Ulm: Kultur und Social werk der Donauschwaben. 1964. p. 64-68.

STEIN, Marcos Nestor. O oitavo dia: produção de sentidos identitários na Colônia Entre Rios-PR. Guarapuava, PR: Editora da UNICENTRO, 2011

STEIN, Marcos Nestor; OLINTO, Beatriz Anselmo; FROTSCHER, Méri. Um Paraná esquecido: deslocamentos, memórias e conflitos em Guarapuava-PR. In: COSTA, Hilton; PEGORARO, Jonas W; STANCZY FILHO, Milton. O Paraná pelo caminho: história, trajetórias e perspectivas Curitiba, PR: Máquina de Escrever, 2017. v. III: movimentos. p. 71-99.

\section{Marcos Nestor Stein}

Doutor em História Cultural pela Universidade Federal de Santa Catarina (UFSC, Florianópolis, SC, Brasil). Professor da Universidade Estadual do Oeste do Paraná (UNIOESTE) em Marechal Cândido Rondon, PR, Brasil. Pesquisador do INCT Proprietas: História Social da Propriedade e Direitos de Acesso.

$\mathrm{PhD}$ in Cultural History, University Federal of Santa Catarina (UFSC, (UFSC, Florianópolis, SC, Brazil). Professor at the Western Paraná State University (UNIOESTE) Marechal Cândido Rondon, PR, Brazil. Researcher at the National Institute of Science and Technology - Social History of Property and Right to Access.

Doctorado en Historia Cultural, Universidad Federal de Santa Catarina (UFSC, Florianópolis, SC, Brasil). Profesor de la Universidad Estatal del Oeste del Paraná (UNIOESTE), Marechal Cândido Rondon, PR, Brasil. Investigador de INCT Proprietas: Historia Social de la Propiedad e de los Derechos de Acceso.

\section{Beatriz Anselmo Olinto}

Doutora em História Cultural pela Universidade Federal de Santa Catarina (UFSC, Florianópolis, SC, Brasil). Professora da Universidade Estadual do Centro Oeste (UNICENTRO), Guarapuava, PR, Brasil. Pesquisadora do INCT Proprietas: História Social da Propriedade e Direitos de Acesso.
PhD in Cultural History, University Federal of Santa Catarina (UFSC, Florianópolis, SC, Brazil). Professor at the Midwestern Parana State University (UNICENTRO), Guarapuava, PR, Brazil. Researcher at the National Institute of Science and Technology - Social History of Property and Right to Access.

Doctorado en Historia Cultural, Universidad Federal de Santa Catarina (UFSC, Florianópolis, SC, Brasil). Profesor de la Universidad Estatal del Centro Oeste (UNICENTRO), Guarapuava, PR, Brasil. Investigador de INCT Proprietas: Historia Social de la Propiedad e de los Derechos de Acceso.

Endereço para correspondência

\section{Marcos Nestor Stein}

Universidade Estadual do Oeste do Paraná. Programa de Pós-Graduação em História

Rua Pernambuco, 1777, Centro, 85960000, Marechal Cândido Rondon, PR, Brasil

\section{Beatriz Anselmo Olinto}

Universidade Estadual do Centro Oeste. Departamento de História

Rua Salvatore Renna, 875, Bairro Santa Cruz, 85015430, Guarapuava, PR, Brasil 